\title{
NECESSITY OF PROTECTING RELIGIOUS FEELINGS UNDER CRIMINAL LAW IN A DEMOCRATIC STATE
}

\section{Paweł SOBCZYK ${ }^{1}$}

Offending religious feelings, as referred to in Article 196 of the Polish Penal Code, was criminalized as follows: 'Any person who offends the religious feelings of others by publicly insulting an object of religious worship or a place dedicated to the public celebration of religious rites shall be liable to a fine, restriction of freedom or imprisonment for a term not exceeding 2 years.' This study highlights some doubts concerning the protection of freedom of conscience and religion using the example of the crime of offending religious feelings and attempts to prove the necessity of such protection in the Republic of Poland, a democratic state ruled by the law. The study first examines whether criminalising offences to religious feelings contravenes the constitutionally and internationally guaranteed freedom of speech (expression), freedom of conscience and religion, and broadly understood democratic standards. The study then examines whether criminal law is too strict an instrument to apply to alleged offences against religious feelings, and whether administrative or civil law (thought to be more lenient) is sufficient for ensuring the protection of individual freedoms and rights in this regard.

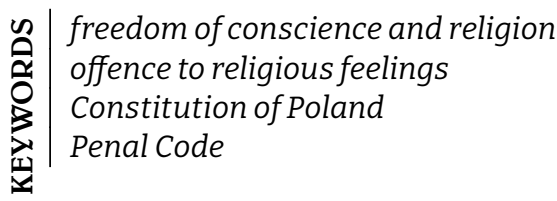

\section{Introductory remarks}

Polish scholarly research on human rights points out that several basic stages can be identified in the development of human rights: idealisation, conceptualisation, positivisation, constitutionalisation, and internationalisation. Our thinking about human rights has reached the stage of practical implementation. Human rights are implemented (realised) by actually protecting individual freedoms and rights, and allowing people to

1 | Associate Professor, Faculty of Law and Administration, University of Opole, Poland, pawel. sobczyk@uni.opole.pl. 
learn about them and exercise them. The purpose of this realisation is to ensure their effectiveness and practical application, so that they are not only theoretical or illusory. ${ }^{2}$

The guarantees of freedom of thought, conscience, and religion enshrined in Article 9 of the European Convention for the Protection of Human Rights and Fundamental Freedoms (ECHR), drawn up in Rome on November 4, $1950^{3}$ ('Everyone has the right to freedom of thought, conscience and religion') provided input for Article 53 of the Polish Constitution", which asserts that 'Freedom of conscience and religion shall be ensured to everyone. ${ }^{5}$ The authors of the Polish Basic Law made efforts to stay close to the wording of the Convention in framing the freedom and rights of individuals, as exemplified by the guarantees of freedom of conscience and religion. ${ }^{6}$

Despite the undeniable position of freedom of conscience and religion in the content and systematics of the chief acts of international and supranational law concerning human rights, as well as the constitutions of most European democratic states under rule of law, the interpretation of this freedom and the application of its guarantees (i.e. realisation) are still problematic.

One of the tasks of contemporary democratic states ruled by law is to establish guarantees and means of protecting individual fundamental freedoms and rights at various legislative levels. The constitution of a state (the basic law) is of key importance in most legal systems (though this does not diminish the role and significance of supranational and international guarantees). Similarly, the framers of the Polish Constitution (April 2, 1997) not only included freedom of conscience and religion (Article 53) among the fundamental freedoms and rights of individuals but also provided the grounds for a system for their protection, including the right to a fair trial and the institution of the Commissioner for Citizens' Rights, the individual constitutional complaint being the most prominent.

This study highlights doubts concerning the protection of freedom of conscience and religion by exploring the crime of giving offence to religious feelings under Article 196 of the Penal Code Act of June 6, 1997 ('Penal Code' or 'PC' hereafter).7 It attempts to establish the necessity of such protection in the Republic of Poland, a democratic state ruled by law. ${ }^{8}$ The study first examines whether the criminalisation of offending religious feelings violates constitutionally and internationally guaranteed freedom of speech (expression), freedom of conscience and religion, and broadly understood standards of a democratic state. Second, the study examines whether criminal law is not too 'strict' an instrument to use to assess acts alleged to have offended religious feelings, and whether administrative or civil law (considered 'more lenient') suffice to ensure the protection of individual freedoms and rights in this regard.

2 | See Jasudowicz, 2005, pp. 22-25.

3 | Journal of Laws of 1993, No. 61, item 284.

4 | Constitution of the Republic of Poland of 2 April 1997, Journal of Laws of 1997, No. 78, item 483 as amended.

5 | As noted by the Constitutional Court, 'Article 53 (1) of the Constitution is about (public authorities) ensuring everyone the freedom of religion (and freedom of conscience)'; Judgement of the Constitutional Court of 2 December 2009, case ref. U 10/07; Judgement of the Constitutional Court of 6 October 2015, case ref. SK 54/13.

6 | See Garlicki, 2001, p. 6.

7 | Act of 6June 1997 - The Penal Code, Journal of Laws of 1997, No. 88 item 553, as amended (consolidated act: Journal of Laws of 2020 , item 1444 , as amended).

8 | Article 2 of the Constitution of the Republic of Poland of 2 April 1997, Journal of Laws No. 78 item 483, as amended. 
I am not an expert in criminal law; my research is conducted from the perspective of constitutional law (the status of an individual) and religious law, so I will not refer to academic discussions among criminal law specialists regarding this legal offence. ${ }^{9}$

\section{The Doda case}

To illustrate the legal issue at hand, let me present a case that has been widely discussed by lawyers and hotly debated in the media for some time - an offence to religious feelings committed by Polish singer Dorota Rabczewska, known as 'Doda'. In an interview she gave on July 24, 2009, and published online by Dziennik.pl on August 3, 2009, Doda said she was convinced by scientific discoveries, not by 'something written by someone drunk with wine and smoking some pot'. When asked by the journalist what she meant, she said, 'All those who wrote down all these incredible [biblical] stories.' ${ }^{10}$

Ryszard N. and Stanisław K. notified the prosecutor's office of a suspected legal offence committed under Article 196 of the Penal Code, pointing out that she offended their religious feelings by mocking biblical authors and the Bible itself, considered a holy book in both Christian religions and Judaism. The prosecutor of the District Prosecutor's Office in Warsaw brought an indictment against the complainant, accusing her of committing the offence under PC Article 196.

In its judgment of January 16, 2012, the court of first instance, in this case the District Court for Warszawa-Mokotów in Warsaw, 3rd Criminal Division, ${ }^{11}$ found the complainant guilty of offending the religious feelings of $\mathrm{R}$. $\mathrm{N}$. and $\mathrm{S}$. K. by publicly offending an object of religious worship (i.e. the authors of the Bible) under PC Article 196, and imposed a fine on her.

After examining the complainant's appeal (Doda was the 'complainant' in the appeal proceedings), the Regional Court in Warsaw, 10th Criminal Appeals Division, by a decision of June $18,2012,{ }^{12}$ amended the challenged judgement, determining that the defendant had committed the alleged act, and imposed a fine on her of PLN 5,000.

The singer decided to use the individual constitutional complaint as provided in Article 79 of the Polish Constitution. Such a complaint may be brought before the Constitutional Court by anyone whose constitutional freedoms or rights have been violated. In essence, it appeals to the consistency with the Constitution of a statute or other legal act, on the basis of which a court or a public administration body has issued a final decision

9 | The contentious issues in interpreting this provision were most aptly pinpointed by Pohl:

[B]ased on both the review of the relevant literature on this provision and the observation of its application, it can be concluded that the construal of the provision in question is very often inconsistent. An analysis of these materials shows that the most serious differences of opinion emerge over two most fundamental matters. In the first of them, the dispute is whether an offence to religious feelings is a formal-only (non-consequential) offence or, contrariwise, a material (consequential) crime. As part of the latter, the discussion touches on the mens rea of the offence. Some support a position allowing only a direct intent, while others favour the view that a conditional intent may also come into play here. (Pohl, 2020, pp. 336-337).

10 | Dziennik.pl, 2010 [Online], http://wiadomosci.dziennik.pl/wydarzenia/artykuly/299624,sadnie-odpuszcza-dodzie-bedzie-proces.html.

11 | Case ref. III K 416/10.

12 | Case ref. X Ka 496/12. 
relating to constitutional freedoms or rights. This means that a precondition for a constitutional complaint to be reviewed substantively is that the complainant must indicate which constitutional freedoms or rights have been infringed on, and in what way, by the decision of a court or a public administration body when issued pursuant to the contested law or provisions of a normative act.

In the case at hand, the issue was the constitutionality of Article 196 of the Penal Code to the extent that it penalises offending the religious feelings of other people by publicly insulting an object of religious worship, punishable by a fine. The crucial point is related to the constitutional problem resulting from the fact that

Article 196 of the Penal Code is an expression of a specific position taken by the legislator in the face of a conflict, which may occur between the freedom to express one's own views (Article 54 of the Constitution) and freedom of religion (Article 53 thereof). The legislator resolved this conflict in favour of freedom of religion, concluding that it is criminal to express views that insult an object of religious worship or a place intended for the public celebration of religious rites, which results in offending other people's religious feelings..$^{13}$

The complainant pointed out that the protection of religious sentiments did not justify interference with freedom of expression so far as to criminalise conduct as a prohibited act subject to public prosecution under the penalty of two years' imprisonment. The complainant claimed that the protection of religious sentiments could be limited to cases in which the insult threatened public order or limited to penalising only a specific action. In her opinion, freedom of religion and conscience is provided a sufficient guarantee by Article 256 of the Penal Code, which penalises hate speech, including public incitement to religious hatred. ${ }^{14}$

Therefore, as argued by the complainant, PC Article 196 restricted freedom (affirmed by Article 54 (1) of the Constitution) to express views in a way that goes beyond the permissible limits specified in Article 31 (3) of the Constitution, particularly beyond what is necessary in a democratic state ruled by law, imposing restrictions in a manner disproportionate to the intended purpose. ${ }^{15}$

\section{Protection of freedom of conscience and religion under the criminal law in Poland}

It is commonly accepted, in both case law and jurisprudence, that freedom of conscience and religion is a fundamental freedom. The obligation to respect it follows chiefly from the principle of human dignity, from which spring the freedoms and rights of people at large and those of citizens in particular. ${ }^{16}$

13 Judgement of the Constitutional Court of 6 October 2015, case ref. SK 54/13, OTK ZU 9A/2015, item 142 .

14 | Judgement of the Constitutional Court of 6 October 2015.

15 | Ibid.

16 | Article 30 of the Constitution. This provision clearly stipulates that '[t]he inherent and inalienable dignity of the person shall constitute a source of freedoms and rights of persons and citizens'. 
Freedom of conscience and religion is included in the first category of freedoms and rights (i.e. personal freedom and rights) in universal and regional acts of international law and in the constitutions of many democratic states governed by law, including the Constitution of the Republic of Poland. This no doubt determines the rank of this freedom among political and civil freedoms and rights. Thus, a profound problem arises when a conflict occurs within the same category of human rights: freedom of speech (expression) is sometimes in conflict with the protection of freedom of conscience and religion but belongs to the same category of individual freedoms and rights (the Doda case), and this aspect is crucial.

Constitutional guarantees regarding conscience and religion are essentially freedoms, ${ }^{17}$ which implies that the drafters of the Polish Constitution laid stress on preventing public authorities and third parties from interfering in the guaranteed sphere of individual behaviours. ${ }^{18}$

The constitutionally upheld legal protection of freedom ('Freedom of the person shall receive legal protection'19) and the right to a fair trial ('Everyone shall have the right to a fair and public hearing of his case, without undue delay, before a competent, impartial and independent court ${ }^{20}$ ) are realised vis-à-vis freedom of conscience and religion, primarily through the guarantees contained in the Civil Code ${ }^{21}$ and the Penal Code. Further, one must not ignore the protection of freedom of conscience and religion under administrative law and through the jurisprudence of the Constitutional Court.

Chapter XXIV of the Penal Code describes offences against freedom of conscience and religion. Religious discrimination (Article 194), malicious interference with a religious act (Article 195 (1)), malicious interference with funerals, ceremonies, or rites (Article 195 (2)), and offending religious feelings (Article 196) have the nature of misdemeanours; therefore, the uniformly specified sanctions are lenient (cf. PC Article 7) and are liable to public prosecution. The offences under Chapter XXIV of the Penal Code are common in the sense that they can be committed by anyone; they can be committed only deliberately, and the offender must be demonstrated to have had a criminal intention (cf. PC Article 9).

Offending religious feelings (as referred to in PC Article 196) was criminalised thus:

Any person who offends the religious feelings of others by publicly insulting an object of religious worship or a place dedicated to the public celebration of religious rites shall be liable to a fine, restriction of freedom or imprisonment for a term not exceeding 2 years.

It follows, then, that the individual protection under criminal law covers the religious feelings of members of a specific religious denomination, ${ }^{22}$ who - wronged by an offender - suffer from at least psychological discomfort, ${ }^{23}$ while type-related protection provided

17 | The wording of Article 53 (1) of the Constitution provides for the freedom of conscience and religion. Nevertheless, the freedom of religion comprises the right of persons to benefit from religious services, wherever they may be (Article 53 (2) in fine) and the right of parents to ensure their children a moral and religious upbringing and teaching in accordance with their convictions (Article $53(3)$ ).

18 | See Wojtyczek, 1999, pp. 24-28.

19 | Article 31 (1) of the Constitution.

20 | Article 45 (1) of the Constitution.

21 | Act of 23 April 1964 - The Civil Code, Journal of Laws, No. 16, item 93, as amended.

22 | Cf. Krukowski, 2008, p. 268.

23 | Cf. Stefański, 2009, p. 248. 
under criminal law refers to freedom of religion. ${ }^{24}$ An offender is liable for public prosecution. ${ }^{25}$ In light of the criminal procedure, however, the proceedings can be initiated by non-public entities (e.g. a victim or third party) reporting a possible legal offence. ${ }^{26}$ Further, the consent of the aggrieved party is not required to initiate and conduct the proceedings. ${ }^{27}$

As a side note, the system of the criminal law protection of freedom of conscience and religion is completed by the qualification of offences involving the use of violence or unlawful threats directed against a group of people or an individual on the grounds of, inter alia, their religious affiliation or religious neutrality, as well as public instigation to commit such an act (Article 119), the offence of insulting a foreign head of state (Article 136 (3)), publicly insulting a group of people or a particular person on the grounds of, inter alia, their religious affiliation or religious indifference (Article 257), and profaning human remains, ashes, or a burial site (Article 262).

\section{Need for criminal law protection of religious feelings in the assessment of the Constitutional Court}

\subsection{Positions of parties to the proceedings}

Before we present the position of the Constitutional Court, which is crucial for this argument, it will be instructive to briefly discuss the positions of the Sejm and the Public Prosecutor General.

The Marshal of the Sejm, in a letter dated June 18, 2014, on behalf of the Sejm, requested that a decision be issued that Article 196 of the Penal Code, to the extent that it penalises offending the religious feelings of other people by publicly insulting an object of religious worship, was consistent with Article 42 (1) in conjunction with Article 2 and Article 54 (1), in conjunction with Article 31 (3) of the Constitution, and that it was not inconsistent with Article 53 (1) in conjunction with Article 54 (1) of the Constitution. Moreover, he requested that the proceedings be discontinued, pursuant to Article 39 (1) of the Constitutional Court Act, due to the inadmissibility of a judgment. ${ }^{28}$

Highlighting the correlations between the specific freedoms and rights indicated in the request (freedom of conscience and religion, freedom of expression), the Sejm upheld the position that PC Article 196 was an instrument for the protection of the freedom expressed in Article 53 (1) of the Constitution and conveyed the legislator's desire to protect religious feelings. In Sejm's opinion, the use of criminal law instruments in Article 196 of the Penal Code, the application of which is limited to sanctioning behaviours that infringe on certain interests related to the religious feelings of an

24 | Cf. Kruczoń, 2011, p. 38.

25 | Cf. also Hypś, 2012, p. 340; Łukaszewicz, 2012, p. C3.

26 | Cf. Article 196 of the PC in conjunction with Article $9 \S 1$ of the Code of Criminal Procedure; cf. also Janyga, 2013, p. 290; Piórkowska-Flieger, 2009, p. 401; Stanisz, 2011, p. 113; Szymański and Jędrejek, 2002, p. 52; Wojciechowska, 2010, p. 901; Wróbel, 2008, p. 556.

27 | I quote the most straightforward description of this offence (contained in the paragraph above) after Poniatowski, 2013, pp. 23-24.

28 | See the Judgement of the Constitutional Court of 6 October 2015, Reasons, point I.2. 
individual, does not constitute an excessive interference with other constitutional rights and freedoms. ${ }^{29}$

The Sejm noted that freedom of speech was not absolute and could be limited in consideration of other constitutional rights and freedoms, particularly the freedom of conscience and religion, which included the right to the protection of religious feelings. PC Article 196 constitutes a proportionate interference with freedom of expression. It applies only to statements that are offensive or contemptuous. Thus, the penalisation of conduct, whose sole purpose is to deride values essential from the point of view of the constitutional rights of individuals, is grounded in the protection of a value, that of freedom of religious belief.

The Public Prosecutor General took a similar position on March 27, 2014. ${ }^{30}$ In his opinion, Article196 of the Penal Code - in its interference with the freedom of conscience of those who are religiously indifferent by preventing them from freely expressing their views about objects of religious worship - was not inconsistent with Article 53 (1) in conjunction with Article 54 (1) of the Constitution; Article 196 of the Penal Code, with regard to the qualities of 'the offence to religious feelings' and 'object of religious worship' as used therein, was consistent with Article 42 (1) in conjunction with Article 2 of the Constitution; and Article 196 of the Penal Code was consistent with Article 54 (1) in conjunction with Article 31 (3) of the Constitution. Moreover, pursuant to Article 39 (1) (1) of the Constitutional Court Act, the Public Prosecutor General concluded that the proceedings were subject to discontinuation due to the inadmissibility of a judgment. The Public Prosecutor General noted as follows:

The challenged provision criminalises not all critical views expressed about objects of religious worship, but only those that harm other people's religious feelings and where the offence consists in publicly insulting an object of religious worship. So, it is about a deliberate conduct of an offender, by which they publicly demonstrate contempt for an object of worship and religious feelings. ${ }^{31}$

In reference to the question alluded to in the introduction (whether criminal law is too strict), we should recall the words of the Public Prosecutor General:

The fact that this provision eliminates any grounds for claiming that the penalty specified in Article 196 of the Penal Code is out of proportion is borne out by its application. In the years 1999-2004, a misdemeanour under PC Article 196 was committed 380 times, with less than $14 \%$ of cases leading to convictions. Of the 50 judgments issued in that period, fines were imposed 13 times, restriction of liberty was used 14 times, and a sentence of conditionally suspended imprisonment was handed down 23 times. In the Prosecutor General's opinion, therefore, we cannot speak of a 'freezing effect' regarding the freedom of expression. ${ }^{32}$

Thus, the Public Prosecutor General concluded that Article 196 of the Penal Code was consistent with Article 54 (1) in conjunction with Article 31 (3) of the Constitution. 
In the judgement of October 6, 2015, the Constitutional Court ruled that Article 196 of the Penal Code Act, to the extent that it penalises offending the religious feelings of other people by publicly insulting an object of religious worship, punishable by a fine, was consistent with Article 42 (1) in conjunction with Article 2 of the Constitution of the Republic of Poland, which is not inconsistent with Article 53 (1) in conjunction with Article 54 (1) of the Constitution, and consistent with Article 54 (1) in conjunction with Article 31 (3) of the Constitution:

The Constitutional Court has found, too, that the object of constitutional review in the present case solely covers Article 196 of the Penal Code to the extent that it penalises offences to religious feelings of other people consisting in publicly insulting an object of religious worship, which are punishable by a fine. The above extent of challenge is relevant to the case in which a constitutional complaint has been lodged..$^{33}$

In its statement of reasons, the Polish Constitutional Court broadly addressed the established views of doctrine as well as the case law regarding the offence referred to in Article 196 of the Penal Code ${ }^{34}$.

\section{| 4.1. The subject: the offender}

It clearly follows from the Penal Code, as well as the positions of jurisprudence and doctrine, that the act described in Article 196 of the Penal Code is universal, which means that anyone with a criminal capacity can commit it. It is immaterial whether the offender is a follower of a specific religion or denomination or religiously indifferent. ${ }^{35}$ At the same time, religious feelings can be insulted only through intentional conduct. On October 29, 2012, the Supreme Court concluded that '[t]he offence specified in Article 196 of the Penal Code is committed by someone who, with their direct or conditional intent, satisfies all the qualities of an offence. ${ }^{36}$ The intentionality of the offender's conduct is an expression of intentionality - that is, an intent which may take the form of 'willing' or 'consenting'.

Religious affiliation is important in relation to those whose feelings have been offended, as one cannot speak of the religious feelings of people who do not belong to any religious denomination.

\section{| 4.2. The object: religious feelings}

The Constitutional Court, by referring to its judgment of June $7,1994,{ }^{37}$ recalled that the constitutional protection of freedom of conscience and religion is expressed, inter alia, in banning violations of religious feelings, which 'due to their nature, are subject to special protection by law. It is so because they are directly related to freedom of conscience and religion, which is a constitutional value'.

In Polish scholarly literature, the object protected under Article 196 of the Penal Code is defined as the freedom of beliefs (feelings) of citizens in matters of faith, resulting from the ideological and philosophical tolerance of a neutral state. ${ }^{38}$ This means that

33 | Judgement of the Constitutional Court of 6 October 2015, Reasons, point III. 2.3.

34 | See e.g. Malec-Lewandowski, 2016, pp. 77-84.

35 | See Budyn-Kulik, 2014, p. 12.

36 | Case ref. I KZP 12/12.

37 | Case ref. K 17/93, OTK (1994), part1, item 11.

38 | Wojciechowska, 2010, p. 899; Kozłowska-Kalisz, 2013, p. 453. 
Article 196 of the Penal Code protects the religious feelings of believers, and therefore 'a certain attitude (mainly emotional) of a certain group to the faith they profess, also manifested in the right to protect the respect for their values and places and objects of worship. ${ }^{39}$ Religious feelings, as an object protected under PC Article 196, are interpreted as people's relationship with the sacrum on a number of levels, be it intentional, volitional, or emotional. ${ }^{40}$

It is also argued that 'The object of the protection under Article 196 of the Penal Code are religious feelings, not protection of a deity, i.e., God.' ${ }^{41}$ Article 196 does not protect 'objects or places of worship themselves, but religious feelings of specific individuals, hurt by the offending conduct of a perpetrator' ${ }^{\prime 42}$ and 'not that which is divine, but that which is human'.43

\section{| 4.3. Offence (insult)}

One should perhaps start discussing the offence against religious feelings by considering the dictionary meanings of the term. In Polish, 'offence' [obraza] is defined as follows:

1. violating by word or deed someone's self-esteem, dignity, honour, insulting, or demeaning someone 2. a person's feeling that their personal dignity has been violated 3. a violation or breaking of the law, of a social or moral rule, or ridicule, mockery of one's respected values. ${ }^{44}$

Synonyms of 'offence' include 'affront', 'dishonour', 'insolence', 'impertinence', 'displeasing', 'misdemeanour', and 'insult'. 45 To 'offend' means to blaspheme, humiliate, abuse, affront, hurt, slander, demean or denigrate someone. ${ }^{46}$ In turn, 'feeling' stands for a sensation, emotion, sense, experience, ${ }^{47}$ and the word 'religious' can mean spiritual, confessional, or denominational. ${ }^{48}$

The key opinion on the term 'offend' is that expressed by the Supreme Court in its judgement of February 17, 1993: 'the term 'offend' has the same meaning (and scope) in all provisions where it refers to a prohibited act.' ${ }^{49}$ This means that the offensive conduct of the perpetrator should therefore be characterised by an expression of contempt, a desire to demean, or ridicule. Nevertheless, the assessment of whether the perpetrator has actually insulted something or someone must be based on cultural and moral rules commonly accepted in society, and therefore on objective criteria. ${ }^{50}$ Hence, Natalia Kłęczyńska concluded that insulting consists of behaving in a way that manifests contempt in light of moral and cultural norms. An insult may take place in any form, either

39 | Hypś, 2015, p. 976.

40 | See Janyga, 2013, p. 592.

41 | Paprzycki, 2008, p. 87.

42 | Kłączyńska, 2014, p. 508.

43 | Warylewski, 2005, p. 370.

44 | My translation of Wielki słownikjęzyka polskiego (Dunaj, 2009, p. 384); the richness of the verbs 'offend' and 'insult' has been pointed out by, among others, Eukasz Pohl.

45 | Cf. Cienkowski, 1990, p. 109; Bańko, 2007, p. 458.

46 | Cf. Cienkowski, 1990, p. 109; Bańko, 2007, p. 459.

47 | Cf. Cienkowski, 1990, p. 215; Bańko, 2007, p. 834.

48 | Bańko, 2007, p. 669.

49 | Case ref. III KRN 24/92, Wokanda, no. 10/1993, p. 8.

50 | See the Judgement of the Supreme Court of 17 February 1993, case ref. III KRN 24/92. 
verbal or written, by gesture, picture, film, installations, or happenings. ${ }^{51}$ The criterion of a prohibited act under PC Article 196 is the public character of the offender's conduct. An object of religious worship can therefore be insulted only in public, in such a way that the conduct in question may be noticed by any given number of persons. Thus, an insult may be disseminated through mass media such as television, the Internet, and the press.

Most of the representatives of the doctrine assume that the crime under Article 196 of the Penal Code has a material nature, and therefore that insulting an object of worship must entail an offence against the religious feelings of specific persons. ${ }^{52}$ The occurrence of offending religious feelings is a necessary but insufficient condition; it needs to have been caused by an insult to an object of religious worship. Therefore, Włodzimierz Wróbel defines an offence to religious feelings as follows:

[a]n emotional reaction of a person related to degrading conduct towards an object, sign, symbol..., which may be accompanied by a sense of violated dignity, a feeling of shame, embarrassment, sorrow. An offence to religious feelings will be a negative reaction going beyond a mere negative opinion on a view or a statement concerning an object of religious worship..$^{53}$

In other words, only the conduct of an offender perceived by a specific person or members of a religious community as demeaning or contemptuous toward an object of religious worship may offend religious feelings. ${ }^{54}$ Lech Paprzycki concludes as follows:

There is no doubt that the offensiveness of a conduct should be assessed on the basis of objective premises. The assessment should refer to the beliefs prevailing in the cultural circle of the aggrieved party. The literature rightly proposes that the average level of sensitivity be taken as a reliable measure. While this is a fairly vague concept, adopting this kind of criterion is essential, as for a very religious person, even undermining the principles of their faith can be hurtful. This is of particular importance in a democratic state ruled by law that observes worldview pluralism, where even acrimonious religious disputes may arise. It is always necessary to distinguish between provocative action, which offends feelings, and the exercise of freedom of conscience involving publicly presentation of different views. We can therefore speak of an offence to feelings only when the offender's conduct oversteps the accepted boundaries of content-related analysis or criticism and becomes a tool for distressing others. ${ }^{55}$

We must now discuss the constitutional freedom of expression (Article 42 of the Constitution of the Constitution of the Republic of Poland) and its limits as set out in Article 31 (3) of the Constitution. In the opinion of the Constitutional Court, the restriction on the freedom to express abusive or offensive views as referred to in Article 196 of the Penal Code unequivocally meets the requirement of statutory regulation and is moreover necessary in a democratic state to ensure the protection of the rights and freedoms of others and also of public order (i.e. the values referred to in Article 31 (3) of the Constitution). As discussed above, the object protected under Article 196 of the Penal Code is the right to protect religious feelings resulting from the constitutional freedom of religion.

51 | See Kłączyńska, 2014, p. 510.

52 | See Budyn-Kulik, 2014, p. 4.

53 | Wróbel, 2013, p. 659.

54 | Ibid., p. 658

55 | Paprzycki, 2000, p. C3. 
By referring to its previous jurisprudence, the Polish Constitutional Court emphasised that

the penalization of offending religious feelings by publicly blaspheming an object of religious worship is therefore to counteract this kind of 'criticism', which consists in replacing, in declared reliance of the freedom of speech, substantive arguments with insults that cannot be an accepted standard in a democratic state..$^{56}$

Blaspheming an object of religious worship aims to deliberately offend other people's religious feelings and harm their personal dignity. The Constitutional Court maintains the position that, in a democratic state, which is the common good of all citizens, a public debate in which everyone is guaranteed the freedom to express their views, including in the religious sphere, should take place in a civilised and cultured manner, without any harm to the rights and freedoms of individuals and citizens. ${ }^{57}$

\section{| 4.4. Object of religious worship}

It follows from Article 196 of the Penal Code that the object of an offender's action is an object of religious worship or a place intended for the celebration of religious rites (i.e. prima facie objects of a material nature). The term 'object of religious worship' should be 'understood as any object that is recognized by a religious community as an object of worship, worthy of the highest respect and adoration ${ }^{158}$ Therefore, an object of religious worship is 'what the worship of a religious nature refers to, whereby worship should be understood as deep respect, associated with a positive view, resulting from the transcendent character (elements) of the object of worship. ${ }^{59}$ In practice, this refers to objects that are actually worshipped and venerated by a religious community (i.e. religious symbols, such as the cross, Star of David, crescent), images and names of God, deities, saints, prophets, icons, relics, holy books, and objects expressing the presence of God. ${ }^{60}$

Most of the representatives of the doctrine, relying on a linguistic, functional, and logical interpretation, recognise that an 'object of religious worship' as defined under Article 196 of the Penal Code includes (in addition to material objects) God, a deity, or deities, understood personally or otherwise, a direct subject of worship, and the source of a denomination or religion. ${ }^{61}$ On the other hand, a minority among the representatives of the doctrine, relying on a linguistic and historical interpretation, recognise that an 'object of religious worship' as described in Article 196 of the Penal Code is limited to material things only and does not include the subject or subjects of such worship. ${ }^{62}$

\section{| 4.5. The penalty}

An offence to religious feelings is punishable by an alternative sanction in the form of a fine, restriction of liberty, or imprisonment for up to two years. In view of the severity of

56 | Judgement of the Constitutional Court of 11 October 2006, case ref. P 3/06.

57 | Cf. Judgement of the Constitutional Court of 6 July 2011, case ref. P12/09.

58 | Wojciechowska, 2010, p. 899.

59 | Wróbel, 2008, p. 659.

60 | Kłączyńska, 2014, p. 512.

61 | See Wróbel, 2008, pp. 659-660; Hypś, 2015, p. 977; Wojciechowska, 2010, p. 900; Kozłowska-

Kalisz, 2013, p. 496; Budyn-Kulik, 2014, p. 8; Janyga, 2013, p. 592; Gardocki, 2007, p. 247.

62 | E.g. Wojciechowski, 1997, p. 340; Filar, 2014, p. 1132. 
the impending penalty, a conditional discontinuation of criminal proceedings is admissible. The court may also refrain from imposing a penalty and limiting itself to imposing a penal measure, unless the offence to an object of religious worship was an act of vandalism. ${ }^{63}$

An offence to religious feelings under Article 196 of the Penal Code is a publicly prosecuted crime. However, the doctrine postulates that the procedure should be changed to prosecution on a complaint ${ }^{64}$ because, whenever they suspect that an object of religious worship has been blasphemed, law enforcement agencies have no instrument under criminal procedure to reach out to specific persons whose religious feelings could be offended in this way.

\section{Summary}

The object protected under Article 196 of the Penal Code is the right to the protection of religious feelings resulting from the freedom of conscience and religion guaranteed in Article 53 (1) of the Constitution of the Republic of Poland. As the Constitutional Court concluded in its judgement on June 7, 1994, religious feelings 'due to their nature, are subject to special legal protection. It is so because they are directly related to the freedom of conscience and religion, which is a constitutional value'.'65

In turn, on October 6, 2015, as is cited several times in this paper, the Constitutional Court indirectly upheld the legitimacy and necessity of protecting freedom of conscience and religion by criminalising offences to religious feelings as in the Penal Code. The doubts raised by the complainant with regard to the specificity of this provision and its consistency with other constitutionally protected values, such as freedom of expression (speech) and of conscience and religion, were resolved by the court, which found that the criminal law protection of religious feelings is consistent with the provisions of the constitution raised in the complaint.

The basic argument supporting the necessity of the criminal law protection of religious feelings in a democratic state is the orientation of the crime towards the protection of the freedom of conscience and religion as an interest protected at the constitutional level. Moreover, freedom of religion occupies a special place in the hierarchy of constitutionally protected interests. This is due not only to the historical, cultural, and social significance of religion, but also to the position of this freedom in the systematics of the Basic Law (among the freedoms and rights of persons) and the means used to protect it, including extraordinary measures. ${ }^{66}$

63 | Cf. Article 59 of the Penal Code.

64 | See Budyn-Kulik, 2014, p. 19.

$65 \mid$ Case ref. K $17 / 93$.

66 That is, the provisions concerning the exercise of constitutional freedoms and rights during martial law, a state of emergency, or a state of natural disaster. It follows from Article 233 (1) of the Constitution of the Republic of Poland that a statute specifying the scope of limitations to the freedoms and rights of persons and citizens in times of martial law and states of emergency may not limit freedom of conscience and religion. Paragraph 3 of that Article provides that the said freedom may not be limited during a state of natural disaster. 
However, realising the guarantee of freedom of conscience and religion as defined under conventions and the constitution by protecting it under criminal law encounters a number of difficulties. Due to the wording of Article 196 of the Penal Code, the doctrine and judicature have interpretative problems related to, inter alia, the evaluative nature of the elements of the crime.

We agree with the reviewer, Pohl, who claims that the objective deficiency in the form of criminalisation of the protection of religious feelings should not lead to decriminalisation. ${ }^{67}$ Hence, the statutory provision must be clarified as part of its amendment, not removed from the Penal Code.

The 'Doda case' confirms that the practical application of the guarantees of freedom of conscience and religion under conventions and the constitution depends on a range of public institutions, not only the judiciary, and on the development of Poland's legal culture.

The implementation and realisation stage of human rights as indicated by the Polish doctrine is not a manifestation of a purely academic concept or debate, but a real stage in the development of human rights. 


\section{Bibliography}

Bańko, M. (ed.) (2007) Wielki Słownik Wyrazów Bliskoznacznych PWN. Warszawa: Wydawnictwo Naukowe PWN.

Budyn-Kulik, M. (2014) 'Znieważenie uczuć religijnych - analiza dogmatyczna i praktyka ścigania', Prawo w działaniu. Sprawy karne 2014/19, pp. 100-137.

Cienkowski, W. (1990) Słownik szkolny. Synonimy. Warszawa: Wydawnictwo Szkolne i Pedagogiczne.

Dunaj, B. (ed.) (2009) Wielki Słownik Języka Polskiego. Warszawa: Wydawnictwo Naukowe PWN.

Dziennik.pl (2010) Sąd Nie Odpuszcza Dodzie. Będzie Proces! Available at: http:// wiadomosci.dziennik.pl/wydarzenia/artykuly/299624,sad-nie-odpuszcza-dodziebedzie-proces.html (Accessed: 7 October 2017).

Filar, M. (2014) ‘Commentary on Article 196' in Filar, M. (ed.) Kodeks Karny. Komentarz, Warszawa: Wydawnictwo LexisNexis, pp. 933-934.

| Gardocki, L. (2007) Prawo Karne. Warszawa: Wydawnictwo C.H. Beck.

Garlicki, L. (2001) 'Przesłanki ograniczania konstytucyjnych praw i wolności (na tle orzecznictwa Trybunału Konstytucyjnego)', Państwo i Prawo 2001/10, pp. 5-24.

Hypś, S. (2012) Przestępstwa Przeciwko Wolności, Wolności Sumienia I Wyznania, Grześkowiak, A. (ed.), Prawo karne. Warszawa: Wydawnictwo C.H. Beck, pp. 340.

Hypś, S. (2015) ‘Commentary on Article 196' in Grześkowiak, A., Wiak, K. (eds.) Kodeks Karny. Komentarz. Warszawa: C.H. Beck 2015, pp. 976-978.

Janyga, W. (2013) 'Commentary on Article 196' in Królikowski, M., Zawłocki, R. (eds.) Kodeks Karny. Część Szczególna Tom I, Komentarz. Warszawa: C.H. Beck, pp. 590-596.

Jasudowicz, T. (2005) 'Zagadnienia Wstępne' in Gronowska B., Jasudowicz, T., Balcerzak, M., Lubiszewski, M., Mizerski, R. (eds.) Prawa Człowieka I Ich Ochrona. Toruń: Towarzystwo Naukowe Organizacji i Kierownictwa Dom Organizatora, pp. 21-33.

Kłączyńska, N. (2014) ‘Commentary on Article 196' in Giezek J. (ed.) Kodeks Karny. Część Szczegółowa. Komentarz. Warszawa: Wolters Kluwer, pp. 508-516.

Kozłowska-Kalisz, P. (2013) 'Commentary on Article 196' in Mozgawa, M. (ed.) Kodeks Karny. Komentarz. Warszawa: Wolters Kluwer, p. 452-453.

Kruczoń, E. (2011) ‘Przestępstwo obrazy uczuć religijnych', Prokuratura i Prawo 2011/2, pp. 38-59.

| Krukowski,J. (2008) Polskie Prawo Wyznaniowe. Warszawa:Wydawnictwo LexisNexis. Łukaszewicz, A. (2012) 'Nie trzeba chcieć, żeby obrazić uczucia religijne', Rzeczpospolita, 30 October 2012, p. C3. 
Malec-Lewandowski, P. (2016) 'Glosa do wyroku Trybunału Konstytucyjnego z dnia 6 października 2015 r. (sygn. akt SK 54/13)', Forum Prawnicze 2016, pp. 75-84.

Poniatowski, M. (2013), 'Analiza art. 196 Kodeksu karnego z perspektywy 15 lat jego obowiązywania', Roczniki Nauk Prawnych Tom XXIII, 2013/3, pp. 23-24.

Paprzycki, L. (2008) 'Czy bluźnierca jest przestępcą? Rozważania na temat znamienia „przedmiotu czci religijnej” przestępstwa obrazy uczuć religijnej - art. 196 k.k.' Palestra 2008/5-6, pp. 81-90.

I Paprzycki, R. (2000) 'Graj szatanie', Rzeczpospolita, 21 September 2000, pp. C3.

Piórkowska-Flieger, J. (2009) 'Commentary on Article 196; in Bojarski T. (ed.) Kodeks Karny. Komentarz. Warszawa: Wydawnictwo Prawnicze LexisNexis, pp. 400-401.

Pohl, Ł. (2020) 'O potrzebie zmiany obecnego ujęcia przepisu określającego przestępstwo obrazy uczuć religijnych w polskim prawie karnym' in Sobczyk P. (ed.) Prawna Ochrona Wolności Sumienia I Religii. Stan De Lege Lata Oraz Postulaty De Lege Ferenda. Warszawa: Wydawnictwo Instytutu Wymiaru Sprawiedliwości, pp. 335-352.

Stanisz, P. (2011) ‘Środki ochrony wolności sumienia i wyznania’ in Mezglewski, A., Misztal, H., Stanisz, P. (eds.) Prawo Wyznaniowe. Warszawa: C.H. Beck, pp. 124-132.

Stefański, R. A. (2009) Prawo Karne Materialne. Część Szczególna. Warszawa: Wydawnictwo Difin.

Szymański, T., Jędrejek G. (2002) Ochrona uczuć religijnych w prawie polskim (Uwagi na tle artykułu Zbigniewa Wiszniewskiego zamieszczonego w Nr 275 „Trybuny" z dnia 25 listopada 1997 r. pt. 'Joannes Paulus dixit'), Warszawa-Sandomierz: Wydawnictwo Diecezjalne w Sandomierzu.

Warylewski, J. (2005), 'Pasja czy obraza uczuć religijnych? Spór wokół art. 196 k.k.' in Leszczyński, E., Hołda, Z. (eds.) W Kręgu Teorii I Praktyki Prawa Karnego. Księga Poświęcona Pamięci Profesora Andrzeja Wąska. Lublin: Wydawnictwo UMCS, pp. 367-381.

Wojciechowska, J. (2010) 'Commentary on Article 196' in Wąsek A., Zawłocki R. (eds.) Kodeks Karny. Część Szczególna. Komentarz Do Art.117-221, vol.1. Warszawa: C.H. Beck, pp. 898-901.

Wojciechowski, J. (1997) Kodeks Karny. Komentarz. Orzecznictwo. Warszawa: Librata.

Wojtyczek, K. (1999) Granice Ingerencji Ustawodawczej W Sferę Praw Człowieka w Konstytucji RP. Kraków: Wydawnictwo Wolters Kluwer.

Wróbel, W. (2008) 'Commentary on Article 196' in Zoll A. (ed.) Kodeks Karny. Część Szczególna. Komentarz, vol. 2, Komentarz do art.117-277k.k.. Warszawa: Wydawnictwo Wolters Kluwer. 